\title{
Exploring teachers' use of TPACK in design talk: The collaborative design of technology-rich early literacy activities
}

Citation for published version (APA):

Boschman, F., McKenney, S., \& Voogt, J. (2015). Exploring teachers' use of TPACK in design talk: The collaborative design of technology-rich early literacy activities. Computers \& Education, 82, 250-262. https://doi.org/10.1016/j.compedu.2014.11.010

DOI:

10.1016/j.compedu.2014.11.010

Document status and date:

Published: 01/03/2015

Document Version:

Early version, also known as pre-print

\section{Document license:}

CC BY-SA

Please check the document version of this publication:

- A submitted manuscript is the version of the article upon submission and before peer-review. There can be important differences between the submitted version and the official published version of record. People interested in the research are advised to contact the author for the final version of the publication, or visit the DOI to the publisher's website.

- The final author version and the galley proof are versions of the publication after peer review.

- The final published version features the final layout of the paper including the volume, issue and page numbers.

Link to publication

\section{General rights}

Copyright and moral rights for the publications made accessible in the public portal are retained by the authors and/or other copyright owners and it is a condition of accessing publications that users recognise and abide by the legal requirements associated with these rights.

- Users may download and print one copy of any publication from the public portal for the purpose of private study or research.

- You may not further distribute the material or use it for any profit-making activity or commercial gain

- You may freely distribute the URL identifying the publication in the public portal.

If the publication is distributed under the terms of Article 25fa of the Dutch Copyright Act, indicated by the "Taverne" license above, please follow below link for the End User Agreement:

https://www.ou.nl/taverne-agreement

Take down policy

If you believe that this document breaches copyright please contact us at:

pure-support@ou.nl

providing details and we will investigate your claim.

Downloaded from https://research.ou.nl/ on date: 26 Apr. 2023 
Exploring teachers' use of TPACK in design talk

PrePrint of: Boschman, F., McKenney, S., \& Voogt, J. (2015). Exploring teachers' use of TPACK in design talk: The collaborative design of technology-rich early literacy activities. Computers \& Education, 82, 250-262.

\section{Introduction}

How teacher knowledge about technology, pedagogy and content is used in the conversations and decision-making processes taking place during collaborative curriculum design, is not well understood. This study was set out to understand the nature of design talk as it occurs in the collaborative design of technology-rich curriculum activities for early literacy and how design talk in teams relate to a teachers' knowledge about technology, pedagogy and content.

In this study, the design talk of one group of teachers is studied in-depth as they create technology-rich lesson modules. They do so within the context of designing content and activities for an early literacy learning environment called PictoPal. PictoPal contains on-computer and off-computer activities. The oncomputer activities take place through a software-based based learning environment featuring teacher-designed content that runs on the Clicker@ offline platform. Clicker@ enables children to create written products. By clicking on ready-made words, text is typed for users and may be checked using the built-in text-to-speech engine. PictoPal off-computer activities, which are also designed by teachers, stimulate children to use prints of their written products for authentic tasks (e.g. stories are read, recipes are cooked, letters are mailed) (McKenney \& Voogt, 2009). Teachers design these activities for their own classroom often within a theme they have selected themselves. Kindergartners then conduct these activities within the 
Exploring teachers' use of TPACK in design talk

daily or weekly routine, making PictoPal a technology enhanced addition to the early literacy learning environment in kindergarten.

The purpose of these learning activities is to foster kindergartners' understanding of the functions of written language, which is one of the Dutch National Early literacy Interim goals (Verhoeven \& Aarnoutse, 1999). While these are featured in the Dutch curriculum, the functions of written language have been recognized internationally, as important areas of early literacy for decades. For example, a pioneer in the field of emergent literacy, Clay (1966) argued that children are active learners about print long before they can read or write. Macnamara (1972) argued that language learning is driven by and dependent on the capacity to understand and participate in social situations. And in recent years, in response to increased research on specific aspects of early literacy (e.g. alphabet knowledge, phonological awareness), experts have expressed deep concern that an over-emphasis on these constrained skills will come at the high cost of developing other abilities, such as oral language, conceptual development and reading/listening comprehension (McKenney, Bradley, Boschman, 2011). This concern seems justified, when looking at existing technologies available to support the development of early literacy. In their landmark review, Lankshear and Knobel (2003) showed that technology is mainly applied to attain development of (a) coding / decoding; (b) vocabulary. They noted that technology use for productive purposes (to assist children in even modest forms of writing) is severely lacking, and called for attention to be given to this area. The PictoPal initiative speaks to this call. The following research question guided this study: "What is the nature of the design talk that emerges when teachers collaboratively design technology-rich early literacy activities in the context of the PictoPal environment?" 


\section{Theoretical framework}

\subsection{TPACK}

Technological Pedagogical Content Knowledge (TPACK) is a form of situated knowledge about the affordances of technology on teaching specific subject matter in a certain context (Mishra \& Koehler, 2006). Several studies employ TPACK as a conceptual framework to understand how teachers explicate their understanding of how knowledge of technology, pedagogy and content interact, for instance during instructional decision-making (Doering, Veletsianos, Scharber, \& Miller, 2009; Graham, 2011). TPACK is considered a distinct body of knowledge, that takes into account teachers' understanding of the difficulties students encounter when they have to learn a particular subject matter domain; in this case kindergarteners learning about early literacy in the context of PictoPal (Voogt, Fisser, Pareja Roblin, Tondeur, \& van Braak, 2013). The TPACK framework posits that three knowledge domains (technological knowledge, pedagogical knowledge and content knowledge) are integrated to form Technological Pedagogical Content Knowledge. In addition the integration between pedagogy and content form Pedagogical Content Knowledge (Shulman, 1986); the integration of technology and content form Technological Content Knowledge; and the integration of technology and pedagogy constitute Technological Pedagogical Knowledge. In this study the TPACK framework is used in the context of PictoPal, and operationalized as follows:

- Pedagogical knowledge (PK): knowledge about kindergarten teaching and learning as well as socio-emotional development of kindergartners;

- Content knowledge (CK): knowledge about early literacy concepts such as phonological awareness, book-reading, vocabulary development; 
- Pedagogical content knowledge (PCK): knowledge about how to apply general instructional strategies in kindergarten to teach and develop early literacy;

- Technological knowledge (TK): general knowledge about technology such as operating computers, web 2.0, email.

- Technological content knowledge (TCK): knowledge about PictoPal that afford the transformation of specific early literacy subject matter;

- Technological pedagogical knowledge (TPK): knowledge about how to use PictoPal in an appropriate kindergarten related fashion such as used to stimulate cooperative learning;

- Technological pedagogical content knowledge (TPCK): how to use the affordances of PictoPal to teach specific early literacy content within a kindergarten appropriate fashion.

In this study we examine how teachers use their TPACK in their conversations during the design of the on- and off computer activities aimed at fostering early literacy in the context of the PictoPal learning environment. Design is a specific context in which TPACK is used, and its use is reflected in design talk.

\subsection{TPACK in design reasoning}

Further investigation of teacher design reasoning as explicated in design talk and how it relates to teachers' TPACK can yield a rich understanding of the factors that drive decision-making during collaborative design of technology-rich activities for student learning. In the context of design, teachers use their TPACK for solving design problems. Design problems are complex and the reasoning to solve these problems is characterized by a multitude of decisions that have to be taken (Jonassen, 2012).

Educational design problems frequently revolve around questions related to achieving certain learning goals. For specific goals we may ask e.g.: What kind of (technologyrich) learning activity seems most effective? How can it be made practical? Efficient? Enjoyable? Many educational design problems are complex, thus providing ample opportunity for teachers to use their TPACK. Design decisions are based on reasons that seem most appropriate to the problem-solver as best suited for the situation at the 
Exploring teachers' use of TPACK in design talk

time (Jonassen, 2012). In an educational context, teachers make such decisions through practical reasoning (Gholami \& Husu, 2010; Wieringa, Janssen, \& Van Driel, 2011). This kind of reasoning involves justifying decisions in classroom practice in terms of 'how' and 'what' is done rather than what is 'true' (Gholami \& Husu, 2010).

In addition to TPACK, other contextual factors also influence decision making during the collaborative design of technology-rich activities for student learning. Scholarship on TPACK and context has found a rich abundance of factors and how these contextual factors influence technology integration (see for instance (Koh, Chai, \& Tay, 2014; Porras-Hernández \& Salinas-Amescua, 2013).

A previous study by Boschman, McKenney and Voogt (2014) conceptualized three kinds of factors that influence design reasoning, providing reasons for 'how' and 'what' is done during the design process: (a) external priorities (priorities set by stakeholders outside the classroom); (b) practical concerns (considerations of feasibility in relation to classroom practice); (c) and existing orientations (convictions, beliefs, knowledge, attitudes, capacities and the habits of mind of teacher-designers themselves). These kinds of factors underpin the ideas, problems and argumentation raised during collaborative curriculum design. A brief elaboration of what is meant with these factors is provided below.

First, curriculum design typically occurs in a context influenced by external priorities set outside the classroom, such as national exams or department policies. When designing, external priorities often focus and/or limit teachers' choices. In most circumstances, teachers are hesitant to make decisions that conflict with external priorities, often because they are at least partially held accountable for pursuing those priorities (e.g. student performance on external exams, teaching certain content in a 
Exploring teachers' use of TPACK in design talk

particular quarter). The Dutch national interim goals for early literacy (see Verhoeven \& Aarnoutse, 1999) are an example of an external priority on content.

Second, teachers' practical concerns, including their perceptions of affordances and constraints in practice, influence their design reasoning (Doyle \& Ponder, 1977). In design conversations these might surface as questions such as "How do we organize this activity?" or "Where are my computers located?" For instance the lack of proper hardware is found to be a barrier to technology integration (Ertmer, 2005). When teachers discuss this point they explicate a practical concern within the domain of technology.

Finally, teachers' existing orientations (such as their own knowledge, beliefs, attitudes and feelings underlie classroom decision-making (Van Driel, Verloop, \& De Vos, 1998) and decision making in regard to curriculum material (Deketelaere \& Kelchtermans, 1996; Drake \& Sherin, 2006; Remillard, 2005). Teachers have gained ample experience in their classroom and they are likely to express these as existing orientations when for instance arguing or providing viewpoints in design talk. For instance teachers beliefs about teaching and learning underlie classroom practice (Ertmer \& Ottenbreit-Leftwich, 2010). These can be considered as falling into the category of existing orientations regarding technology and pedagogy.

While TPACK in design reasoning reflects the topics under discussions, how these topics are addressed, the kind of inquiry that is reflected in these discussions furthermore yields richer understanding of design talk. 
Exploring teachers' use of TPACK in design talk

\subsection{TPACK in collaborative inquiry}

Design decisions are made in collaborative inquiry, as teachers discuss possible solutions to the problem at hand. The nature of design talk can therefore be characterized as a form of inquiry where teachers use their TPACK and take external priorities, practical concerns and existing beliefs into account when they design technology-rich activities for student learning. Schön (1992) examines Dewey’s notion of inquiry, as a systematic, rigorous and critical path from doubt to its resolution. In design such inquiry is focused on solving a design problem at hand. Collaborative design inquiry therefore is the act of reaching resolution of a design problem by means of deliberation, discussion and exploration. This complex cognitive task takes skills and teachers combine what they know, believe and understand about teaching and learning, subject matter and technology. While some qualitative studies have investigated the contents of discussions (e.g. Koehler, Mishra, \& Yahya, 2007), the inquiry process has not been subject of investigation.

Collaborative inquiry processes are intelligible in conversations (Frederiksen, 1999; Hmelo-Silver \& Barrows, 2008; Rojas-Drummond, Mazón, Fernández, \& Wegerif, 2006; Wegerif, Mercer, \& Dawes, 1999). Literature on collaborative inquiry processes in conversations suggests two levels (a) shallow and (b) deep. For instance Wegerif, et al. (1999) found that shallow depth is reached through cumulative talk (for instance by sharing information). On the other hand, exploratory talk (Wegerif et al., 1999), shows collaborative engagement and critical discussion reflecting deeper levels of inquiry. Inspired by the new taxonomy of learning objectives (Marzano \& Kendall, 2007), Henry (2012) depicted four levels of depth differentiated in collaborative teacher conversation: (1) No inquiry, (2) Sharing and Reacting, (3) Analyzing and Generalizing; and (4) Planning and Problem-solving. Using this 
typology, Henry (2012) explored the inquiry process reflected in teacher teams' discussions. These discussions revolved around trying new and innovative forms if instruction. Inspired by these distinctions, this study discerns four levels of depth of inquiry in design talk: (1) no collaborative inquiry; (2) shallow inquiry by sharing knowledge and information; (3) deep inquiry that builds understanding by analyzing and synthesizing new information; and (4) using understanding to achieve learning goals in novel situations by planning. Problem solving entails both analyzing as well as planning activities and is therefore seen as a form of deep inquiry.

For each level of inquiry, various forms of TPACK might be used. One example for each level of inquiry is provided to illustrate this. 'Maybe we can use a digital story book' - reflects shallow inquiry because the computer is proposed as an option. If for instance another teacher would react by stating: ' ... maybe, but there would have to be many illustrations because kindergartners are not able to read,' then this would reflect deeper inquiry, as one teacher counter-argues for the previous proposal. Finally, when disagreement is reached, teachers might plan in detail what the learning activity will look like. This can be reflected for instance as: 'So basically we are saying that all key ideas in the book must be illustrated such that the children can interpret the story without reading any words.' The difference between sharing and planning is that in sharing no decision is explicated while in planning the decision is explicit and on details of the learning activity. From time to time, it is hypothesized that collaborative inquiry reaches the deeper levels of inquiry (analyze and plan).

Therefore, collaborative teacher inquiry certainly seems a context in which TPACK develops as the results of integrating the knowledge domains of technology, pedagogy and technology. To date there are no studies that link inquiry processes in 
Exploring teachers' use of TPACK in design talk

conversation to TPACK. Since design talk is mostly conversation, it would seem necessary to also unpack this specific feature of design talk.

\subsection{Aims of the study}

This study was set out to understand the nature of design talk as it occurs in the collaborative design of technology-rich curriculum activities for early literacy and how design talk in teams relate to a teachers' integrated knowledge about technology, pedagogy and content.

The main question of the study is: "What is the nature of the design talk that emerges when teachers collaboratively design technology-rich early literacy activities in the context of the PictoPal environment?" In the design talk of one group of teachers, this study investigates which TPACK domains are represented, how TPACK is linked to explicated design reasoning; and what levels of inquiry are present. The sub-questions addressed in this study are therefore stated as follows:

1. Which TPACK domains are represented in the design talk of the teacher team?

2. How is TPACK linked to explicated design reasoning in the design talk of the teacher team?

3. How does depth of inquiry in the design talk of the teacher team relates to TPACK?

\section{Methods}

A single, holistic, explorative case study was conducted on the design-talk of one team of kindergarten teachers creating PictoPal materials and activities. This data-analysis method was employed in order to obtain an in-depth understanding of the complex interactions that underlie design talk. The teams' design talk was 
explored in terms of the TPACK used, design reasoning explicated, and the depth of inquiry present.

\subsection{Participants}

An open call to three school districts was issued requesting participation in a project regarding professional development of kindergarten teachers in the domains of technology and early literacy yielded in one team of teachers. Thus this school was automatically selected for this study (Table 1 provides information on participating teachers). Furthermore the teachers expressed that they wanted to learn about technology integration in early literacy. A preliminary on-site meeting was arranged to explain the goal of the project and to get acquainted with all six participating teachers. After this preliminary meeting, all six teachers agreed to voluntarily participate in the project. These teachers had an average age of $58,8(\mathrm{SD}=5,08)$ and an average of $30,3(\mathrm{SD}=6,34)$ years of teaching experience, all in kindergarten. Additionally one teacher-coordinator requested to participate in the study out of interest and because the other six teachers endowed her with the role of being an experienced teacher as well as an expert in the field of young-children's education.

This teacher was 58 , had 31 years of teaching experience.

Table 1. Description of participating teachers abbreviated name, age years of experience in kindergarten and experience in using ICT.

\begin{tabular}{|l|l|l|l|}
\hline $\begin{array}{l}\text { Abbreviated } \\
\text { name }\end{array}$ & Age & $\begin{array}{l}\text { Years of } \\
\text { experience in } \\
\text { kindergarten }\end{array}$ & Experience in using ICT \\
\hline $\mathrm{H}$ & 56,00 & 30,00 & $\begin{array}{l}\text { Curious, experiments with using ICT in } \\
\text { kindergarten }\end{array}$ \\
\hline $\mathrm{J}$ & 48,00 & 26,00 & Skeptic, has little experience in ICT \\
\hline $\mathrm{Y}$ & 61,00 & 40,00 & Curious, but has little experience in using ICT \\
\hline $\mathrm{Al}$ & 58,00 & 37,00 & Curious, does not use computers frequently \\
\hline $\mathrm{P}$ & 53,00 & 28,00 & Skeptic, has little experience in using ICT \\
\hline $\mathrm{An}$ & 47,00 & 24,00 & Curious, has little experience in using ICT. \\
\hline
\end{tabular}


Exploring teachers' use of TPACK in design talk

\subsection{Procedure}

The overall design task was explained to all teachers during the preliminary meeting: "using the existing PictoPal structure, design on- and off-computer activities, to be implemented in your own classroom" (3 classrooms were involved). These learning activities were directed at a specific learning goal: kindergartners attainment of their understanding of the functions of print, one of the national interim goals for early literacy. After the preliminary meeting, three workshops took place. The first author took the role as outside facilitator. The teacher coordinator $(G)$ who was also liaison of the school did preside over the meetings and provided input, yet taught in a different grade level. However, she requested that she would be present during two of the workshops. The facilitator organized the workshops and set the agendas. The individual workshops lasted approximately 50 minutes.

At the teachers' own request, the first workshop focused on creating a draft version of one integrated set of on- and off- learning-activities (children compose grocery lists, and then use printed lists to shop for those items in a grocery shop playcorner). In the following weeks, PictoPal was installed, the draft set of learning activities were used by several children and teachers' could experience how PictoPal would behave in their classroom. The goal of the second and third workshops was to plan and design a lesson-series of eight PictoPal learning activities (one for each week). On request, the facilitator also provided background information about PictoPal and how it contributes to child understanding of the functions of written language. One teacher $(\mathrm{P})$ missed the first two workshops; however, this study focuses on the teams' design conversations and not the individual teacher and therefore not considered problematic. 
Exploring teachers' use of TPACK in design talk

\subsection{Data collection and analysis}

Data were collected by video-taping the three meetings of the design-team and making a transcript of the audio portions; the video allowed us to identify who was talking. With design talk as unit of analysis, this study focused (a) on TPACK reflected in the conversations; (b) explicated design reasoning in relation to TPACK; and (c) depth of inquiry in relation to TPACK.

First the conversations were segmented into episodes: larger units of text that sustained focus on one topic over a longer period of time or were similar in tone. Then, each episode was segmented into topical exchanges (TEs): sections in episodes that sustained focus on sub-topics. Two rounds of coding practice and discussion were held among all three authors. Thereafter an experienced research assistant recoded TEs in a part of the transcript (roughly $20 \%$ of the transcript of workshop 1 ). After discussion, reliability was calculated yielding Cohen's Kappa of .76, which was deemed sufficient. TEs were coded along the categories of TPACK (TK, PK, CK, TPK, TCK, PCK, TPCK). Table 2 provides examples of the TPACK-codes used in TEs.

Table 2. Examples of TE coding pertaining to TPACK

\begin{tabular}{|c|c|c|}
\hline Code & Topics reflect & Example \\
\hline$<\mathrm{Tk}>$ & $\begin{array}{l}\text { Use of computers without } \\
\text { referencing to learning or } \\
\text { teaching. }\end{array}$ & $\begin{array}{l}\text { "And where is that computer located? Outside our } \\
\text { classroom? Well that's not going to work for me!" }\end{array}$ \\
\hline$<\mathrm{Pk}>$ & $\begin{array}{l}\text { General teaching and } \\
\text { learning strategies or } \\
\text { learning activities in } \\
\text { kindergarten. }\end{array}$ & $\begin{array}{l}\text { "Well I think it is important to fold from time to } \\
\text { time." }\end{array}$ \\
\hline$<\mathrm{Ck}>$ & $\begin{array}{l}\text { Subject-matter regarding } \\
\text { early literacy }\end{array}$ & "Maybe we could include words like 'much', 'less'." \\
\hline$<\mathrm{TPk}>$ & $\begin{array}{l}\text { Use of computers related to } \\
\text { teaching / learning and } \\
\text { classroom practice in } \\
\text { kindergarten. }\end{array}$ & $\begin{array}{l}\text { "Well you know, some children can't even operate a } \\
\text { mouse." }\end{array}$ \\
\hline$<\mathrm{TCk}>$ & Use of computers to & "But in some sentences the word 'cat' has to be used. \\
\hline
\end{tabular}


Exploring teachers' use of TPACK in design talk

\begin{tabular}{|c|c|c|}
\hline & $\begin{array}{l}\text { represent subject matter } \\
\text { knowledge. }\end{array}$ & That should be included in the program." \\
\hline$<\mathrm{PCk}>$ & $\begin{array}{l}\text { Strategies to promote the } \\
\text { development of early } \\
\text { literacy. }\end{array}$ & $\begin{array}{l}\text { "Well... you have the childrens' own story, or at least } \\
\text { how I think children will divide the story } \\
\text { themselves... and they have to 'tell' it in their own } \\
\text { words?" }\end{array}$ \\
\hline$<\mathrm{TPCk}>$ & $\begin{array}{l}\text { Strategies or affordances of } \\
\text { the computer in regard to } \\
\text { early literacy development. }\end{array}$ & $\begin{array}{l}\text { "And children who are not yet ready to use a } \\
\text { computer? Why would you want them to write their } \\
\text { own story?" }\end{array}$ \\
\hline
\end{tabular}

Second, the TEs were also coded on explicated design reasoning (see Table 3)

using the three dimensions described previously (Practical Concerns, Existing

orientations, External priorities). TEs were then given an overall TPACK and design

reasoning code which represented the TE best.

Table 3. Description of codes pertaining to explicated design reasoning.

\begin{tabular}{|l|l|l|}
\hline Code & Topic reflects & Example \\
\hline$<$ Pract $>$ & $\begin{array}{l}\text { Organization of activities, } \\
\text { time and other practical } \\
\text { concerns. }\end{array}$ & $\begin{array}{l}\text { "Could you also install those printers then?" } \\
\text { "..those computers are so slow, the first thing you } \\
\text { should do in the morning is turning them on." }\end{array}$ \\
\hline$<$ Orient $>$ & $\begin{array}{l}\text { Teachers own attitudes, } \\
\text { beliefs, practical knowledge. }\end{array}$ & $\begin{array}{l}\text { "I can imagine a child wants to write something on } \\
\text { it himself." }\end{array}$ \\
\hline$<$ Extern $>$ & $\begin{array}{l}\text { Priorities set by others } \\
\text { outside the classroom. }\end{array}$ & $\begin{array}{l}\text { "[name] states that you should let children write } \\
\text { themselves..." }\end{array}$ \\
\hline
\end{tabular}

Finally, each TE was given a 'depth of inquiry' code using Table 4. Therefore

TEs received three different categories of code (TPACK, Explicated design reasoning and Depth of Inquiry).

Table 4. Description of codes pertaining to depth of inquiry from shallow to deep and codes pertaining to the kind of reasoning that was found.

\begin{tabular}{|l|l|l|}
\hline Code & $\begin{array}{l}\text { Description } \\
\text { In the conversation, teachers: }\end{array}$ & Example \\
\hline$<$ None $>$ & $\begin{array}{l}\text { ․exchange topics that have no apparent } \\
\text { link. No inquiry is present. }\end{array}$ & $<$ No example present $>$ \\
\hline$<$ Share $>$ & $\begin{array}{l}\text { ‥brainstorm on possible solutions or } \\
\text { goals. In rapid succession teachers share } \\
\text { information, viewpoints, opinions or } \\
\text { beliefs however they do not question or } \\
\text { argue. Solutions are generated without }\end{array}$ & $\begin{array}{l}\text { H: "I was thinking something like } \\
\text { making a grocery list..." } \\
\text { A: "Shopping list.." } \\
\text { J: "But if you do it like that }\end{array}$ \\
\hline
\end{tabular}




\begin{tabular}{|c|c|c|}
\hline & providing arguments or considerations. & \\
\hline$<$ Analyze $>$ & $\begin{array}{l}\text {...delve deeper into a topic by } \\
\text { generating more information, } \\
\text { explaining, exemplifying, examining, } \\
\text { analyzing or otherwise manipulating } \\
\text { information, knowledge or } \\
\text { understanding. }\end{array}$ & $\begin{array}{l}\text { G: "That's wonderful isn't it?" } \\
\text { H: "Yes, that is their own book!" } \\
\text { G: "Then it becomes their own work." } \\
\text { H: "As long as they 'kind of' stick to } \\
\text { the story.." }\end{array}$ \\
\hline$<$ Plan $>$ & $\begin{array}{l}\text {...delve deeper but also find solutions to } \\
\text { problems, they make decisions for } \\
\text { which they provide explicit reasons or } \\
\text { make a detailed planning of steps to be } \\
\text { taken. }\end{array}$ & $\begin{array}{l}\text { G: "Okay, I imagine you take several } \\
\text { books as an example and show that to } \\
\text { them." } \\
\text { H: "Yes, and then you discuss what the } \\
\text { table of contents is and then you move } \\
\text { on to the contents of the book itself." } \\
\text { G: "Maybe you could also discuss this } \\
\text { afterwards." }\end{array}$ \\
\hline
\end{tabular}

\section{Findings}

\subsection{Overall presentation of findings}

The data-analysis resulted in a table for each workshop on the level of TEs (see Appendix). The first column (TE) identified the TE in relation to the corresponding episode (2.2.1 means workshop 2, episode 2, TE 1). The second column (topic) provided a summary of the TE focus. The third column (TPACK) contained the TPACK code (illustrated in Table 2). The fourth column (reason) showed explicated design reasoning codes (described in Table 3). In the final column (depth), depth of inquiry is given (shown in Table 4). The following sections discuss the findings in detail, in relation to each sub-question. Names are not provided; the first letter of the name is represented in the text to ensure anonymity. The researcher present as facilitator is denoted as F. In workshop 1, six teachers were present; in workshop 2 four teachers were present and in workshop 3 three teachers were present among which one teacher (R) who had just started teaching after workshops 1 and 2 
Exploring teachers' use of TPACK in design talk

were held. Although the group's composition varies, they worked to produce one lesson-series that they all would implement.

\subsection{RQ1: Which TPACK domains are represented in design talk?}

In workshop 1, before the discussion was initiated, teachers requested to make a draft version of PictoPal. The design-task was formulated as: "Design one PictoPal on and off-computer learning activity." The rest of the workshop was devoted to working out the details of this learning activity; writing a grocery list on the computer and using this grocery list in a play-corner. In workshop 1, four out of seven possible TPACK codes were found: TK, CK, PCK and TPCK, which were distributed evenly across the 13 TEs.

In workshop 2, teachers first evaluated the prototype learning activity and concluded that due to technical difficulties with the printer, the results were poor. The issue could not be resolved at that time as the schools' ICT-coordinator was not present. Furthermore, a large number of TEs were coded as PCK (14 out of 23). According to the summaries (see tables in Appendix), topics under discussion pertain to practices in early literacy education off-computer. Yet after TE 2.5.6, topics are mostly coded as TPCK. While the goal of this workshop was to discuss both offcomputer and on-computer activity, in this workshop the focus clearly is on offcomputer activities first before moving towards on-computer activity or integration of both kinds of learning activities. Interesting also is the emergence of 3 TEs coded as CK in which for instance the early literacy learning goal was discussed. The findings show that, in this workshop, teachers focused on the off-computer learning activity, as most TEs were coded as PCK. 
Exploring teachers' use of TPACK in design talk

In TE 5.1 to 5.8 teachers' team's rationale for further design activities is discussed. TE 5.1 to 5.6 were coded as PC; after TE5.7 most TEs were coded as TPCK and that when investigating the topics, the rationale that was provided is reflected in the topics under discussion. Also interesting in this light is TE 5.8 in which Y makes an inference on how the use of pictograms will support children in performing this activity, she states:

“...they 'write' because the words that they do not yet know are represented as a pictogram. They use these pictograms as sort of anchors."

Y makes an inference on the affordance of the computer as it facilitates children's story writing.

In workshop 3, the goal was to finalize the on-computer learning activity. It should be noted that during this final workshop teacher R was introduced as one of the new members of the design team, and that only teachers $\mathrm{Y}$ and $\mathrm{H}$ were present during the workshop. $\mathrm{R}$ had just commenced her teaching duty after a short period of leave. The other two teachers $(\mathrm{Y}$ and $\mathrm{H})$ first focused their attention on explaining to her the learning activity that was designed in workshop 2. R expressed various concerns: kindergartners find it difficult to use a computer, children with reading disability have a hard time using PictoPal and difficulty in finding appropriate words to be included in PictoPal. Y and H managed to relinquish R's concerns.

In this workshop most TEs were coded as TPCK (11 out of 29), evenly distributed across the conversation. 8 out of 29 TEs were coded as PCK, pertaining to the learning activity off-computer. In this workshop 3 TEs were coded as T; 2 were coded as C; 3 were coded as TPK and 2 were also coded as TC. While it was expected that the focus of the discussions would be on finalizing, $\mathrm{R}$ expressed doubts about the appropriateness of PictoPal and this in turn influenced the contents of the TEs. First of 
Exploring teachers' use of TPACK in design talk

all she expressed doubt about kindergartners using computers as she found them not yet able to use a mouse. Further down the discussion, she also expressed her concerns about how the use of words that could not be easily read could (a) be an impediment for children with emerging reading disabilities; (b) looming prospect of children not being taught the appropriate spelling of words. These topics did not just get explicated by $\mathrm{R}$, rather $\mathrm{Y}$ and $\mathrm{H}$ managed to relinquish the doubts that $\mathrm{R}$ expressed. At the end of workshop 3 teachers discuss topics such as how to best represent words in PictoPal, the kind of words appropriate to use in PictoPal and how these relate to other early literacy topics.

The rationale that was discussed in workshop 2 (children should write their own stories), is repeated at the end of workshop 3 in TE 8.4 and does not get questioned or changed even when contrasted with an external priority or R's doubts about the usefulness of PictoPal. In this TE, once more Y repeats this rationale with which P agrees.

While the tables provide an overview of the flow of topics addressed within each workshop, Figure 1 shows frequencies of TPACK codes distributed accross each workshop. This illstrates TPACK development over time. Striking is the absence of TEs coded as PK, the small total number of TEs coded as $\mathrm{CK}(\mathrm{N}=5)$ and the abbundance of TEs coded as PCK ( $\mathrm{N}=25)$ and TPCK (20).

The graph shows that over time the number of TEs coded as TPCK increases, that the number of TEs coded as PCK rises in workshop 2, but declines in workshop 3. What this graph also shows is that in all three workshops TEs emerged that were coded as either TK, PCK or TPCK. In workshop 1 no TEs emerged coded as CK, while in the other workshops TEs were found pertaining to CK. 
Figure 1. Graph showing per count of TPACK codes found in all three workshops

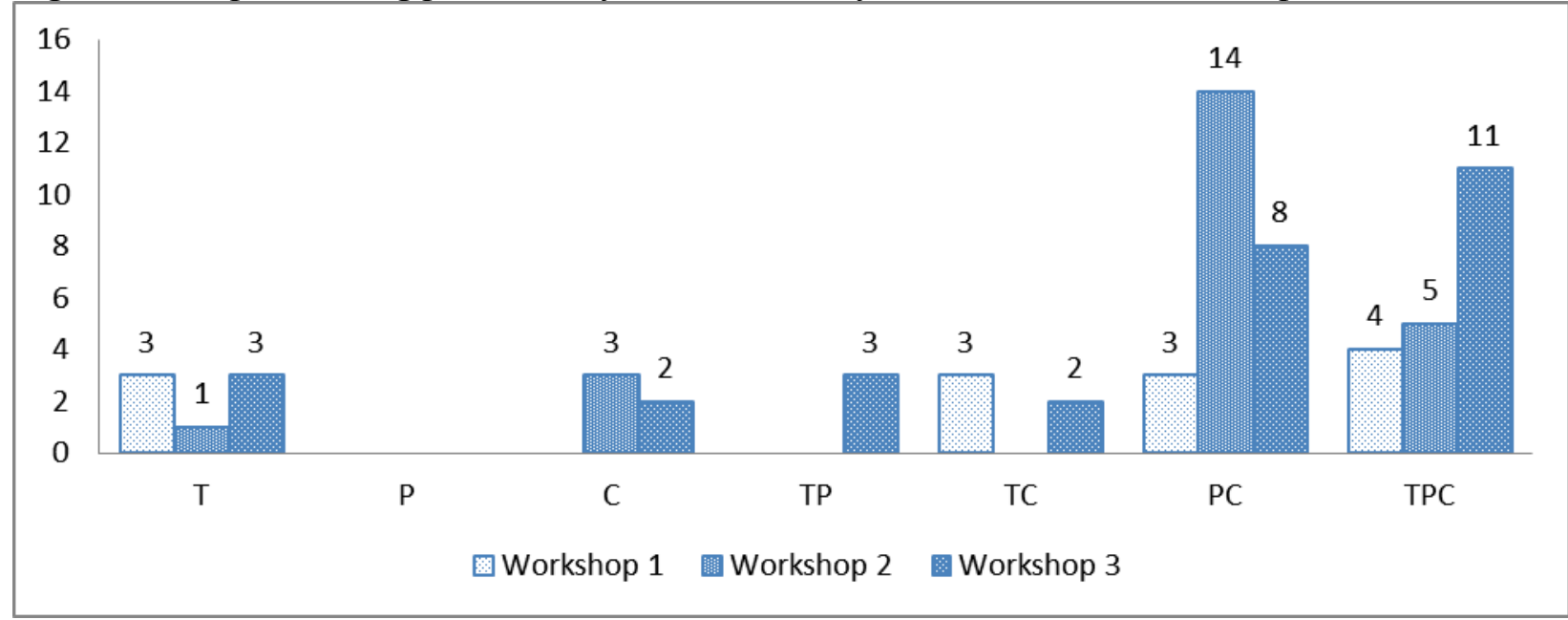

\subsection{RQ2: How is TPACK linked to explicated design reasoning in the design talk}

This research question focused on how the topics were explicated as either practical concerns (regarding organization of the activity); existing orientations (teachers beliefs and knowledge) or external priorities (of other stakeholders such as school board or principal), and how these relate to TPACK. For each workshop, tables are provided in which the distribution is tabulated of each of the coded TEs. The rows represent the kind of design reasoning, the columns represent TPACK.

Table 5 reveals that all but one TE was coded as practical concern in workshop 1. In workshop 2, most TEs were also coded as practical concern and PCK. Striking however are patterns found. First, that of the four out of six TEs coded as existing orientations pertained to PCK. Second, TEs coded as $\mathrm{C}(\mathrm{N}=3)$ pertained to external priorities $(\mathrm{N}=2)$ or existing orientations. TEs 5.7 (about nouns) and 5.9 (invented spelling) were initiated by a question from one of the teachers, while TE 2.2 
was initiated by the researcher. The third workshop sees a rise in the emergence of TEs coded as TPC and practical concerns (7).

Overall, in the three workshops TEs coded as PCK and as TPCK in combination with practical concerns make up the main body of codes used $(\mathrm{N}=39)$. Also within workshops, most TEs were coded as practical concerns (workshop 1, 12 TEs; workshop 2, 15 TEs and workshop 316 TEs). Regarding TEs coded as PC or TPCK and practical concerns: in workshop 1 TPACK codes are distributed evenly (PC : TPC; $3: 3)$; in workshop 2 the emphasis is on PCK (10:4) and in workshop 3 on TPC (2:7). Also notable is the pattern regarding TK and TCK: all TEs in these domains were coded as practical concerns. Finally, there was a notable pattern regarding C: none of these, throughout all three workshops, was coded with practical concerns.

Over time, Table 5 reveals that the number of TEs coded as practical concern increases. However the number of TEs that were coded as either orient or extern also increase, with the number of TEs coded as extern showing a steep incline $(0-2-6)$. Also, in concurrence with Figure 1, the number of TEs coded as PCK and practical concerns increases in workshop 2, but decreases again in workshop 3 . The number of TEs coded as TPCK and practical concerns however steadily increases. Table 5 also shows that TEs coded as PCK / external and TPCK / external emerge only in workshop 3.

Table 5. Number of TEs assigned to each code (reasoning and TPACK) in workshop 1,2 and 3

\begin{tabular}{|c|c|c|c|c|c|c|c|c|c|}
\hline Workshop & Design Reasoning & TK & PK & $\mathbf{C K}$ & TPK & TCK & PCK & TPCK & Total \\
\hline 1 & $\begin{array}{l}\text { Practical concern } \\
\text { Existing orientation } \\
\text { External priority }\end{array}$ & 3 & & & & 3 & 3 & $\begin{array}{l}3 \\
1\end{array}$ & $\begin{array}{l}12 \\
1 \\
0\end{array}$ \\
\hline 2 & $\begin{array}{l}\text { Practical concern } \\
\text { Existing orientation } \\
\text { External priority }\end{array}$ & 1 & & $\begin{array}{l}1 \\
2\end{array}$ & & & $\begin{array}{l}10 \\
4\end{array}$ & $\begin{array}{l}4 \\
1\end{array}$ & $\begin{array}{l}15 \\
6 \\
2\end{array}$ \\
\hline 3 & $\begin{array}{l}\text { Practical concern } \\
\text { Existing orientation }\end{array}$ & 3 & & & $\begin{array}{l}2 \\
1\end{array}$ & 2 & $\begin{array}{l}2 \\
4\end{array}$ & $\begin{array}{l}7 \\
2\end{array}$ & $\begin{array}{l}16 \\
7\end{array}$ \\
\hline
\end{tabular}


Exploring teachers' use of TPACK in design talk

\begin{tabular}{|l|l|lllllll|l|}
\hline & External priority & & & 2 & & 2 & 2 & 6 \\
\hline & & 7 & 0 & 5 & 3 & 5 & 25 & 20 & 65 \\
\hline
\end{tabular}

\subsection{RQ3: How does depth of inquiry in the design talk relates to TPACK?}

This research question focused on the depth of inquiry in design talk and how this relates to TPCK and explicated design reasoning. First the quantitative analysis of the distribution of depth of inquiry coded among TEs is provided. Seen in Table 6, there is a shift over time across all three workshops. Second to provide a more in-depth portrayal of this shift, a qualitative analysis of provides insight into how sharing occurred in workshop 1; how sharing evolves into analysis in workshop 2 and finally a portrayal of how analysis in workshop 3 occurs on the basis of external priorities. As witnessed in table 10, of all TEs coded $(\mathrm{N}=65)$ most TEs were coded as Share $(\mathrm{N}=39)$; followed by Analyze $(\mathrm{N}=21)$, Plan $(\mathrm{N}=4)$ and None $(\mathrm{N}=1)$. Of the TEs coded as Analyze, in workshop 2, three were found to be on PCK, two on TPCK; workshop 3, six were coded as PCK, two were coded as TPCK. Of the TEs coded as share in workshop 2, most were coded as PCK $(\mathrm{N}=8)$ while in workshop 3, most were coded as TPCK $(\mathrm{N}=7)$. Across all three workshops, TEs coded as T were only found to be coded as either None $(\mathrm{N}=1)$ or Share $(\mathrm{n}=6)$. Across all three workshops, a change occurs when considering TEs coded as pertaining to PCK or TPCK; in workshop 1 both of these were coded as pertaining to shallow inquiry (none or share); in workshop 2, most TEs were coded as pertaining to share, however 7 also emerge as pertaining to deeper inquiry (analyze or plan); in workshop 3 most of those TE codes pertain to deeper inquiry (total $n=10$ ). 
Table 6. Number of TEs assigned to each code (depth of inquiry and TPACK) in workshop 1,2 and 3

\begin{tabular}{|c|c|c|c|c|c|c|c|c|c|}
\hline Workshop & Depth & TK & PK & CK & TPK & TCK & PCK & TPCK & Total \\
\hline 1 & $\begin{array}{l}\text { None } \\
\text { Share } \\
\text { Analyze } \\
\text { Plan }\end{array}$ & 3 & & & & $\begin{array}{l}1 \\
2\end{array}$ & 3 & $\begin{array}{l}3 \\
1\end{array}$ & $\begin{array}{l}0 \\
10 \\
3 \\
0 \\
\end{array}$ \\
\hline 2 & $\begin{array}{l}\text { None } \\
\text { Share } \\
\text { Analyze } \\
\text { Plan }\end{array}$ & 1 & & $\begin{array}{l}1 \\
2\end{array}$ & & & $\begin{array}{l}8 \\
3 \\
2\end{array}$ & $\begin{array}{l}4 \\
2\end{array}$ & $\begin{array}{l}0 \\
14 \\
7 \\
2 \\
\end{array}$ \\
\hline 3 & $\begin{array}{l}\text { None } \\
\text { Share } \\
\text { Analyze } \\
\text { Plan }\end{array}$ & 3 & & 2 & $\begin{array}{l}2 \\
1\end{array}$ & 3 & $\begin{array}{l}1 \\
6\end{array}$ & $\begin{array}{l}7 \\
2 \\
2 \\
\end{array}$ & $\begin{array}{l}0 \\
16 \\
11 \\
2 \\
\end{array}$ \\
\hline & & 7 & 0 & 5 & 3 & 6 & 23 & 22 & 65 \\
\hline
\end{tabular}

Table 6 reveals a change over time when looking at the columns PCK and TPCK. Emphasis in workshop 1 seems to be on sharing, PCK and TPCK are evenly distributed. In workshop 2 the emphasis is still on share, yet seems to shift to analyze ( $\mathrm{N}=3$ for PCK and $\mathrm{N}=2$ for TPCK). Plan is only found 2 times on PC and is small. In workshop 3 emphasis in TPCK is still on sharing, while emphasis in PCK has shifted towards analyze. Such shifts are indicative for teachers' evolving understanding in both PCK and TPCK. The following section presents the qualitative findings in which subsequently the inquiry processes for each workshop are provided as excerpts from actual discourse. These excerpts were carefully chosen to illustrate and portray an account of how such inquiry processes occur in conversation. 
Exploring teachers' use of TPACK in design talk

\subsubsection{Workshop 1: Sharing}

Table 7 presents an excerpt from turn 13 to 24 ,which occurred in workshop 1.

This excerpt picks up after the researcher has explained the kind of learning activity that has to be designed. This excerpt depicts shallow inquiry, teachers share their ideas and viewpoints yet there is little constructive conflict. Although arguments are made they do not influence the decisions made.

\section{Table 7. Excerpt of workshop 1, showing a shift in depth of inquiry}

\begin{tabular}{ll}
\hline Turn & Excerpt \\
\hline 13 & H: I was thinking about a grocery list. \\
14 & E: Pricelist? \\
15 & H: Really simple, I was thinking like something with which they can make their own \\
& list. I thought that if you make a grocery list, than eh... 'I buy'- I'm not sure if there \\
& is a pictogram for that... I buy a chestnut, or I buy a sweater, depending on what you \\
& have in our store, and that they will make this at-forehand. And that becomes their \\
& list. And you have pictograms or photos of these items from your shop.. \\
16 & G: But that's also what you mean J? \\
17 & J: Yes. \\
19 & G: Or do you have another idea? \\
& J: Well, if you say it like this, than they will be engaged for a while.. and then well \\
& organization.. I kind of like quick and... I would, do this the day before, they will \\
20 & store. \\
21 & H: Yeah, but I think... \\
22 & G: But do can do this within a larger theme, but not as a small playing activity. \\
23 & J and H: Yes, we are going to make one. \\
24 & H: But then you have like, one can be the shop owner, the other can buy something. \\
& Isn't that fun, they first make a list and then, that's part of their work, they take a \\
shopping basket and head of to the store to get it. What they want.
\end{tabular}

This excerpt shows that at line 19 , $\mathrm{J}$ concludes and makes conjectures about what would occur in practice ("will be engaged for a while..."). This is then taken as an argument to substantiate how she thinks the activity should be organized ("I would, do this the day before..."). However, this argument does not elicit any counterarguments from the other teachers. In line $20, \mathrm{H}$ hesitates but does not finish 
Exploring teachers' use of TPACK in design talk

her sentence, which could be seen as an argument which is withdrawn. Then in line $21, \mathrm{G}$ brings up a whole other matter, namely the kind of theme and activity that could be appropriate. This excerpt furthermore shows that the practical concern is not shared among other teachers, they do not recognize this concern and ignore J's call for action. Instead, in line 24 design talk commences by sharing ideas on the specific learning activity.

\subsubsection{Workshop 2: from share to analyze}

As already noted in RQ2 and RQ3 TEs 5.1 through 5.8 signal the emergence of a rationale being explicated. This episode starts with Y explicating how in her view children will respond the learning activity:

“But what if Johnny prints out 'mother' and wants to tell his story about the evil stepmother and then Anny also wants to... and do you have to say, well you can do both about.. because you would get two versions on the same page of that story.."

$\mathrm{H}$ proposes then designate each child with one part of the fairytale. However, Y makes a refuting statement and expounds her view:

"But a child wants to 'churn out', just does not want to... alone with those..." Interesting is the fact that in the following TEs especially in TE 2.5.8, a rationale is being explicated and agreed upon by all teachers. The following excerpt picks up at the moment where once more Y shares with the other teachers her view on how the learning activity will take form in her classroom.

Table 8. Excerpt in which in workshop 2, the rationale is repeated and outweighs external priorities

Turn Transcript 
Exploring teachers' use of TPACK in design talk

147 Y: So... you get one sentence, made up of six pictures. No letters... yeah, well 'the castle'.. but I mean..

148 R: Pictures

149 Y: And they do not have to write anything themselves?

150 H: ... I think that a child feels the need...

151 Y: Yes!

152 H: I think a child wants tell more about, and that you write this down, and a child would write down.. If someone says: "The miller also had a cat." And he thinks about his own cat who gets milk and kibbles, you can also write that down as well...

153 R: Yeah

154 Y: But then you would need extra space and you cut and paste. Then you would need extra space.

155 H: Yes, but you just need to!

156 Y: But I don't know if we are allowed to...

157 R: Yes, you can.

158 Y: Oh, so we can...

159 R: That's all possible, anything you all think of...

160 Y: Yes, but I think those pictograms are kind of 'anchors' of that day, and by means of those anchors they go about... writing or drawing or...

The excerpt shown in Table 8 reveals that Y's comment on children's own written work is taken up by $\mathrm{H}$ who in line 152 expresses how she thinks a child will react to the learning activity. Y's argument is taken up by $\mathrm{H}$, who not only repeats it but also extends with her existing orientation. This signals agreement between the two teachers about the rationale behind PictoPal as it will function in their classroom. Furthermore in line 160, Y then draws a conclusion: "But then the pictograms are kind of anchors that provide children scaffolding into making their own story." This conclusion is also agreed upon by other teachers. This clearly shows how understanding of the affordance of technology gets translated to the teachers own beliefs about teaching and learning early literacy, integrating PCK with T to form TPCK. 
Exploring teachers' use of TPACK in design talk

\subsubsection{Workshop 3: Analyze external priorities}

It is notable that, while in this workshop P introduces many concerns, none defy the rationale which was solidified in workshop 2 . Tensions do rise in the conversations but rather provide opportunity to strengthen rather than weaken the 'power' of the teachers' personal rationale for use of PictoPal. See for instance Table 9, showing the excerpt at the end of the workshop in which an external priority regarding early literacy is discussed. The arguments that teachers use reflect their existing orientations on PCK as translated into the context of Technology. Reasoning therefore first is based on teachers' existing orientations about how children develop early literacy and then implications are made on how this is integrated with technology.

Table 9. Excerpt in which in workshop 3, the rationale is repeated and outweighs external priorities

\section{Turn Transcript}

557 I: No, not of they write something on a drawing. But if they write a story about a bike...

558 R: JS (Dutch early literacy expert, name is disclosed)... she also discusses this.. she's like... 'look what I have written!', like we said before, and then... you would raise their motivation. And there will come a point in time that they just know how to write the word correctly.

559 F: And that's important.

560 R: Than you sort of build... in first grade you have to write words correctly..

561 Y: Yes, but I would like to know, a child likes to tell his story.. otherwise you would stifle this don't you?

562 H: Yes, but... if ...you say "you did not write this correctly"... Well I would not say it like this, but... you would block their enthusiasm.

563 Y: Of course!

The excerpt in Table 9 shows that an external priority (Turn 558) is being outweighed by the rationale (Turn 561). After this TE, R once more mentions an external priority, yet this does not influence the rationale teachers explicated in workshop 2. 


\section{Conclusion and discussion}

This study was set out to understand the nature of design talk as it occurs in the collaborative design of technology-rich curriculum activities for early literacy and how design talk in teams relate to a teachers' integrated knowledge about technology, pedagogy and content. The design talk that occurred was explored on topics under discussion and how these topics were addressed.

The first research question focused on the TPACK domains that were reflected in the topics under discussion. The findings revealed that teachers spend most of their time on PCK and TPCK; explications reflecting separate domains of knowledge (TK, PK, CK) are scarce. Pedagogy is explicated in relationship with the other three possible constellations of knowledge domains (TPK, PCK, TPCK). Regarding TPK, teachers focus on whether or not technology is appropriate or what kind of practice using technology is appropriate in kindergarten. Regarding PCK, knowledge about teaching and learning reflect specific application in teaching and learning early literacy. This becomes most clear in the explication of the teachers' rationale: "Children write their own story." Furthermore, while in workshop 2 the number of TEs coded as PCK rises, in workshop 3, this number declines. Finally, the number of TEs coded as TPCK gradually increases which is concurrent with findings from the study by Koehler et al. (2007). Based on these findings, this study suggests that teachers base their collaborative design decisions on integrated knowledge domains rather and that teachers actually gain understanding of how these three bodies of knowledge intertwine, which is considered characteristic in TPACK development (Koehler et al., 2007; Mishra \& Koehler, 2006). 
Exploring teachers' use of TPACK in design talk

Research question 2 focused on how TPACK is related to design reasoning in design talk. Practical concerns stay important, most TEs were coded as such, but the number of TEs coded as existing orientation increase over time. Most of these existing orientations pertain to PCK. They reflect beliefs and knowledge about teaching early literacy. Most TEs coded as TPCK also pertained to practical concerns. The findings would suggest that teachers use their existing orientations to reason about their rationale and once this rationale is established teachers integrate technology and discuss practical concerns.

The third research question focused on how depth of inquiry relates to TPACK in design talk. The findings showed that over time teachers reached deeper inquiry levels. The emphasis throughout all three workshops was on sharing, yet a slight increase was found in deeper levels of inquiry. In workshop 2 and in workshop 3, while the majority of the TEs were coded as share, the amount of TEs coded as either analyze increased. The TEs coded as plan did not increase and were clearly lower in number, only four were found. The findings of this study furthermore show that teachers' existing orientations regarding teaching and learning early literacy then are employed during analysis. By contrasting different perspectives and by making implications or arguing for or against a certain solution, teachers reach a deeper level of inquiry. Furthermore, 'plan' is hardly found, suggesting that actual design is mostly done by sharing proposals. Striking is that TPCK gets shared mostly as practical concern in such proposals. Only towards the end of workshop 2 TPCK is explicated during analysis as existing orientation. Contrasting, at the end of workshop 3, external priorities and existing orientations are discussed, but only coded as PCK regarding appropriate kindergarten practices in early literacy. This would suggest that over time teachers better understand the complexity of the design problem in terms of practical 
Exploring teachers' use of TPACK in design talk

concerns and how technology, pedagogy and subject-matter act together; yet analysis still occurs on the affordance of teachers' existing orientations reflecting PCK. This would suggest that in collaborative design teachers existing orientations towards early literacy are translated to classroom practice.

This study differentiated between non-existing, shallow and deeper levels of inquiry. The findings of this study suggest that design is an iterative process. This is not surprising, given that design is a reflective activity in which actions are taken and often designers 'step-back' to evaluate the actions taken (Hong \& Choi, 2011; Schön, 1983). In this study the findings show a pattern that is similar: teachers share knowledge and information by proposing what the learning activity could look like, this process is repeated until one teacher either expresses doubt or makes an evaluative comment about the learning activity, which is then followed by action. Striking is that action is mainly taken through sharing. Analyzing is an inquiry process in which not only teachers build understanding but also reflect on actions taken. It is in such moments that TPACK could develop.

The findings of this study should be considered in light of its inherent limitations. First of all, the analysis was conducted on a relatively small group of teachers, during three workshops. While this would limit generalization, this study does provide a rich account of TPACK development as it occurred in the design talk of one team. The approach to studying design conversations about TPACK is a new perspective to the ongoing investigation into building understanding of TPACK. This study has shown that methods of discourse and conversation analysis help to shed light on TPACK development. Future studies could extend this approach to studying interactions of teachers in different contexts. Although design serves as a rich context for teacher learning, the narrow time-frame of the study, it is unclear whether 
Exploring teachers' use of TPACK in design talk

participation as a designer alone or design-talk that occurs underlies TPACK development. The problem being that both are difficult to distinguish since designtalk is the product of collaborative design. Therefore, TPACK development is reflected in design talk as teachers integrate what they know about teaching and learning early literacy with technology. Further research is needed in order to establish and understand how TPACK is linked to design talk.

This study's findings point to practical implications on the level of support provided to teachers during collaborative design. The complexity of design problems, stresses the need for support. Teachers often use an unsystematic and intuitive approach to design problem solving (Hoogveld, 2005). Two kinds of support exist. The first, procedural support is considered a minimal pre-requisite for productive teacher teams (cf. Huizinga, Handelzalts, Nieveen, \& Voogt, 2013). In this study, procedural support was provided through the researcher-facilitator, in the form of worked examples, and by chunking the overall design work into three workshop sessions featuring smaller yet open-ended tasks. Previous research suggests that teacher design teams also benefit from substantive (i.e. subject-matter) support. Such support is provided as just in time information (cf. Kester, Kirschner, van Merriënboer, \& Baumer, 2001; van Merriënboer, 2013), by a subject-matter expert especially when teachers struggle. In this study, the results show that teachers struggle when discussing topics that reflect CK. A subject-matter expert could provide teachers with information before and during the design. Often teachers struggle in translating abstract subject-matter knowledge to practical solutions (cf. Handelzalts, 2009), for which a subject-matter specialist could provide insights and information. Desirable then would also be that a subject-matter specialist is present during actual design talk when teachers struggle. 
Exploring teachers' use of TPACK in design talk

The findings of this study are corroborated by findings from other studies that show the learning potential of (a) collaborative problem solving through conversation (Hmelo-Silver \& Barrows, 2008); and (b) solving complex design problems (Jonassen, 2000; Kolodner et al., 2003). Contemporary studies on teacher workplace learning also stress the importance of inquiry processes (Putnam \& Borko, 2000) such as those investigated in this study. Further, teachers in this study did engage in activities known to foster teacher learning in terms of changes in knowledge and/or beliefs and intentions for practice (Bakkenes, Vermunt, \& Wubbels, 2010); these include: experimenting, reflecting, collaborating, problem-solving, analysis (Vermunt \& Endedijk, 2011). This means that design talk not only reflects TPACK development as integrating knowledge about pedagogy, content and technology, but that this occurs in and through various levels of inquiry. Summarizing, this study has explored TPACK in design talk, and while myriad aspects of design talk could still be investigated, we have come closer to understanding how TPACK development can be understood. 


\section{References}

Bakkenes, I., Vermunt, J. D., \& Wubbels, T. (2010). Teacher learning in the context of educational innovation: Learning activities and learning outcomes of experienced teachers. Learning and Instruction, 20(6), 533-548. doi: DOI: 10.1016/j.learninstruc.2009.09.001

Clay, M. (1966). Emergent Reading Behaviour. Unpublished doctoral dissertation, University of Auckland, New Zealand.

Deketelaere, A., \& Kelchtermans, G. (1996). Collaborative curriculum development: an encounter of different professional knowledge systems. teachers and Teaching: theory and practice, 2(1), 16.

Doering, A., Veletsianos, G., Scharber, C., \& Miller, C. (2009). Using the Technological, Pedagogical, and Content Knowledge Framework to Design Online Learning Environments and Professional Development. Journal of Educational Computing Research, 41(3), 319-346.

Doyle, W., \& Ponder, G. A. (1977). The practicality ethic in teacher decision-making. Interchange, 8(3), 1-12. doi: 10.1007/bf01189290

Drake, C., \& Sherin, M. G. (2006). Practicing Change: Curriculum Adaptation and Teacher Narrative in the Context of Mathematics Education Reform. Curriculum Inquiry, 36(2), 153-187. doi: 10.1111/j.1467-873X.2006.00351.x

Ertmer, P. (2005). Teacher Pedagogical Beliefs: The Final Frontier in Our Quest for Technology Integration? (EJ732691) Educational Technology Research and Development, 53(4), 16.

Ertmer, P., \& Ottenbreit-Leftwich, A. (2010). Teacher Technology Change: How Knowledge, Confidence, Beliefs, and Culture Intersect. Journal of Research on Technology in Education, 42(3), 255 -284.

Frederiksen, C. H. (1999). Learning to reason through discourse in a problem-based learning group. Discourse Processes, 27(2), 135-160. doi: 10.1080/01638539909545055

Gholami, K., \& Husu, J. (2010). How do teachers reason about their practice? Representing the epistemic nature of teachers' practical knowledge. Teaching and Teacher Education, 26(8), 1520-1529. doi: http://dx.doi.org/10.1016/j.tate.2010.06.001

Graham, C. R. (2011). Theoretical considerations for understanding technological pedagogical content knowledge (TPACK). Computers \& Education, 57(3), 1953-1960. doi: 10.1016/j.compedu.2011.04.010

Handelzalts, A. (2009). Collaborative curriculum development in teacher design teams. (PhD Doctoral), Universiteit Twente, Enschede.

Henry, S. (2012). Instructional Conversations: A Qualitative Exploration of Differences in Elementary Teachers' Team Discussions. (ED Doctoral Dissertation), Harvard University.

Hmelo-Silver, C. E., \& Barrows, H. S. (2008). Facilitating Collaborative Knowledge Building. Cognition and Instruction, 26(1), 48-94. doi: 10.1080/07370000701798495 
Hong, Y.-C., \& Choi, I. (2011). Three dimensions of reflective thinking in solving design problems: a conceptual model. Educational Technology Research and Development, 59(5), 687-710. doi: 10.1007/s11423-011-9202-9

Hoogveld, A., Paas, F., Jochems, W.,. (2005). Training higher education teachers for instructional design of competency-based education: Product-oriented versus process-oriented worked examples. Teaching and Teacher Education, 21, 287297.

Jonassen, D. (2000). Toward a design theory of problem solving. Educational Technology Research and Development, 48(4), 63-85. doi: 10.1007/bf02300500

Jonassen, D. (2012). Designing for decision making. Educational Technology Research \& Development, 60(2), 341-359. doi: 10.1007/s11423-011-9230-5

Kester, L., Kirschner, P. A., van Merriënboer, J. J. G., \& Baumer, A. (2001). Just-intime information presentation and the acquisition of complex cognitive skills. Computers in Human Behavior, 17(4), 373-391. doi: Doi: 10.1016/s07475632(01)00011-5

Koehler, M. J., Mishra, P., \& Yahya, K. (2007). Tracing the development of teacher knowledge in a design seminar: Integrating content, pedagogy and technology. Computers \& Education, 49(3), 740-762.

Koh, J. H. L., Chai, C. S., \& Tay, L. Y. (2014). TPACK-in-Action: Unpacking the contextual influences of teachers' construction of technological pedagogical content knowledge (TPACK). Computers \& Education, 78(0), 20-29. doi: http://dx.doi.org/10.1016/j.compedu.2014.04.022

Kolodner, J. L., Camp, P. J., Crismond, D., Fasse, B., Gray, J., Holbrook, J., . . . Ryan, N. (2003). Problem-based learning meets case-based reasoning in the middle-school science classroom: Putting Learning by Design (TM) into practice. Journal of the Learning Sciences, 12(4), 495-547. doi: 10.1207/s15327809j1s1204_2

Lankshear, C., \& Knobel, M. (2003). New Technologies in Early Childhood Literacy Research: A Review of Research. Journal of Early Childhood Literacy, 3(1), 59-82. doi: 10.1177/14687984030031003

Macnamara, J. (1972). Cognitive basis of language learning in infants. Psychological Review, 79, 1-12.

Marzano, R. J., \& Kendall, J. S. (2007). The new taxonomy of educational objectives: Corwin Press.

McKenney, S., Bradley, B. \& Boschman, F. (2011). Assessing Teacher Beliefs about Early Literacy Curriculum Implementation. Paper presented at the AERA conference New-Orleans.

McKenney, S., \& Voogt, J. (2009). Designing technology for emergent literacy: The PictoPal initiative. Computers \& Education, 52, 719-729.

Mishra, P., \& Koehler, M. (2006). Technological Pedagogical Content Knowledge: A Framework for Teacher Knowledge. Teachers College Record, 108(6), 10171054.

Porras-Hernández, L. H., \& Salinas-Amescua, B. (2013). Strengthening TPACK: A broader notion of context and the use of teacher's narratives to reveal knowledge construction. Journal of Educational Computing Research, 48(2), 223-244. 
Putnam, R., \& Borko, H. (2000). What Do New Views of Knowledge and Thinking Have to Say About Research on Teacher Learning? Educational researcher, 29(1), 4-15. doi: 10.3102/0013189x029001004

Remillard, J. T. (2005). Examining Key Concepts in Research on Teachers' Use of Mathematics Curricula. Review of Educational Research, 75(2), 211-246.

Rojas-Drummond, S., Mazón, N., Fernández, M., \& Wegerif, R. (2006). Explicit reasoning, creativity and co-construction in primary school children's collaborative activities. Thinking Skills and Creativity, 1(2), 84-94. doi: http://dx.doi.org/10.1016/j.tsc.2006.06.001

Schon, D. (1992). Designing as reflective conversation with the materials of a design situation. Research in Engineering Design, 3(3), 131-147. doi: 10.1007/BF01580516

Schön, D. A. (1983). The Reflective Practitioner: How Professionals Think in Action: Basic Books.

Shulman, L. S. (1986). Those Who Understand: Knowledge Growth in Teaching. Educational researcher, 15(2), 4-14.

Van Driel, J., Verloop, N., \& De Vos, W. (1998). Developing science teachers' pedagogical content knowledge. Journal of Research in Science Teaching, 35(6), 673-695.

van Merriënboer, J. J. G. (2013). Perspectives on problem solving and instruction. Computers \& Education, 64(0), 153-160. doi: http://dx.doi.org/10.1016/j.compedu.2012.11.025

Verhoeven, L., \& Aarnoutse, C. (1999). Tussendoelen beginnende geletterdheid: Een leerlijn voor groep 1 tot en met 3. . Nijmegen: Expertisecentrum Nederlands.

Vermunt, J. D., \& Endedijk, M. D. (2011). Patterns in teacher learning in different phases of the professional career. Learning and Individual Differences, 21(3), 294-302. doi: http://dx.doi.org/10.1016/j.lindif.2010.11.019

Voogt, J., Fisser, P., Pareja Roblin, N., Tondeur, J., \& van Braak, J. (2013). Technological pedagogical content knowledge - a review of the literature. Journal of Computer Assisted Learning, 29(2), 109-121. doi: 10.1111/j.13652729.2012.00487.x

Wegerif, R., Mercer, N., \& Dawes, L. (1999). From social interaction to individual reasoning: an empirical investigation of a possible socio-cultural model of cognitive development. Learning and Instruction, 9(6), 493-516. doi: http://dx.doi.org/10.1016/S0959-4752(99)00013-4

Wieringa, N., Janssen, F. J. J. M., \& Van Driel, J. H. (2011). Biology Teachers Designing Context-Based Lessons for Their Classroom Practice-The importance of rules-of-thumb. International Journal of Science Education, 33(17), 2437-2462. doi: 10.1080/09500693.2011.553969 


\section{Appendix}

Table A. Workshop 1 data coding

\begin{tabular}{|c|c|c|c|c|}
\hline TE & Topic & ТРСК & Reason & Depth \\
\hline 1.1 & $\begin{array}{l}\text { After an example PictoPal on-computer activity is shown, G asks why } \\
\text { in PictoPal lower-case letter are used; this is purely a matter of taste. } \\
\text { The design task is discussed: design one on-computer and off-computer } \\
\text { activity within the PictoPal framework. }\end{array}$ & TCK & Pract & Share \\
\hline 1.2 .1 & $\begin{array}{l}\text { Initial design discussion on learning activity. } \mathrm{H} \text { proposes that children } \\
\text { write their own grocery list on the computer and use this list to shop for } \\
\text { items in the grocery-store. }\end{array}$ & TPCK & Pract & Share \\
\hline 1.2 .2 & $\begin{array}{l}\text { Organizational problem, printers are located outside of the classroom. J } \\
\text { states "that does not work for me!" }\end{array}$ & TK & Pract & Share \\
\hline 1.2 .3 & $\begin{array}{l}\text { H proposes that children write "I buy...". J opposes this and states that } \\
\text { nobody writes this on a grocery list. Also G opposes H's proposal by } \\
\text { stating that writing short sentences is "further down early literacy } \\
\text { development" }\end{array}$ & PCK & Pract & Analyze \\
\hline 1.2 .4 & $\begin{array}{l}\text { Teachers discuss how the learning goal of PictoPal is addressed. R } \\
\text { repeats the goal of PictoPal: "children discover the functions of print" } \\
\text { G makes the implication that "it can also be done with single words". } \\
\text { H however objects by stating that "I buy will provoke more discussion } \\
\text { among child and adult" }\end{array}$ & TPCK & Orient & Analyze \\
\hline 1.3 & $\begin{array}{l}\text { On-computer activity: brainstorm about the items that should be } \\
\text { written on the grocery list. }\end{array}$ & TPCK & Pract & Share \\
\hline 1.4 .1 & $\begin{array}{l}\text { On-computer activity. H proposes to add numbers to the grocery list } \\
\text { but also questions whether this would be too complicated. R responds } \\
\text { by showing how this would look on the computer screen and that } \\
\text { individual nouns should than also be presented as plurals. For instance } \\
\text { the word 'cup' should also be presented as 'cups'. }\end{array}$ & TCK & Orient & Share \\
\hline 1.4 .2 & $\begin{array}{l}\text { G proposes that instead of numbers the words 'much' and 'less' are } \\
\text { used. R also shows what this would look like on screen. Thereafter, G } \\
\text { decides that this would be too complicated. }\end{array}$ & TCK & Pract & Analyze \\
\hline 1.5 & $\begin{array}{l}\text { F initiates the second part of workshop 1's design task: integrate on- } \\
\text { computer and off-computer learning activity. A responds first by } \\
\text { stating that since the computers are "slow to start. We should first turn } \\
\text { on the computers." }\end{array}$ & TK & Pract & Share \\
\hline 1.6 .1 & $\begin{array}{l}\text { Organizing on-computer and off-computer integration. H warns that } \\
\text { teachers should keep a list of children who made the grocery list and } \\
\text { have been using this list during a play activity. }\end{array}$ & TPCK & Pract & Share \\
\hline 1.6 .2 & $\begin{array}{l}\text { Jokingly, H states that A "is going to fold wallets" at which point A } \\
\text { expresses "I think it is important for kindergartners to fold every now } \\
\text { and then!"" }\end{array}$ & PCK & Pract & Share \\
\hline 1.6 .3 & $\begin{array}{l}\text { H states that it is important to evaluate the children's work by } \\
\text { displaying it to the whole classroom and have the child expound on his } \\
\text { or her work. }\end{array}$ & PCK & Pract & Share \\
\hline 1.7 & $\begin{array}{l}\text { Workshop is finished, teachers state that they would like the printer to } \\
\text { be installed next to their classroom. F will consult on this with the } \\
\text { school's ICT-coordinator (a teacher from one of the upper grades } \\
\text { endowed with the duty to oversee any ICT related matter). }\end{array}$ & TK & Pract & Share \\
\hline
\end{tabular}

Table B. Workshop 2 data coding

\begin{tabular}{|l|l|l|l|l|}
\hline TE & Topic & TPCK & Reason & Depth \\
\hline $\begin{array}{l}\text { G evaluates on the try-outs and is disappointed because the ICT- } \\
\text { coordinator refused to install the printers; the reason being a pending } \\
\text { school-wide hardware-upgrade. F reacts that the matter will be } \\
\text { discussed with the ICT-coordinator, however also states that he is }\end{array}$ & TK & Pract & Share \\
\hline
\end{tabular}




\begin{tabular}{|c|c|c|c|c|}
\hline & bound by limitations set him. & & & \\
\hline 2.1 .2 & $\begin{array}{l}\text { Design task, create } 8 \text { PictoPal on-computer and off-computer lesson } \\
\text { activities, aimed at the attainment of functional literacy. Teachers } \\
\text { respond by formulating the theme of PictoPal will be fairytales since } \\
\text { PictoPal will be implemented in a school-wide fairytale-related theme- } \\
\text { period. }\end{array}$ & PCK & Pract & Share \\
\hline 2.2 .1 & $\begin{array}{l}\text { Learning activity: G proposes to make a fairy-tale book, which is } \\
\text { applauded by Y stating "that's what I would like best, making a fairy- } \\
\text { tale book." }\end{array}$ & PCK & Pract & Share \\
\hline 2.2 .2 & $\begin{array}{l}\text { F repeats and explains the goal of PictoPal's learning activity which } \\
\text { garners G's reaction "I can imagine that you write a fairytale, because } \\
\text { such is a wonderful early literacy activity." H then responds by } \\
\text { proposing that children start by designing the front of the book. }\end{array}$ & $\mathrm{CK}$ & Orient & Analyze \\
\hline 2.2 .3 & $\begin{array}{l}\text { Grouping of children is discussed, kind of off-computer learning } \\
\text { activity and how a well-known fairytale is used as a basis of children's } \\
\text { own version of a fairytale. }\end{array}$ & PCK & Pract & Share \\
\hline 2.3 & $\begin{array}{l}\text { F repeats the design task and specifies that a series of } 8 \text { lessons is made } \\
\text { with as much detail as possible. G reflects "well that's a rather hefty } \\
\text { assignment! Let's make a framework for the lessons first." }\end{array}$ & PCK & Pract & Share \\
\hline 2.4 .1 & $\begin{array}{l}\text { Learning activity, details: Brainstorm is initiated in which teachers } \\
\text { propose various learning activities. }\end{array}$ & PCK & Pract & Share \\
\hline 2.4 .2 & $\begin{array}{l}\text { Reason for learning activity. F states that the learning activity should } \\
\text { also be discussed on a higher level of abstraction. Teachers respond: } \\
\text { "at our school children write a lot, hence in his learning activity they } \\
\text { will also write." Furthermore they explain that they believe it is } \\
\text { important for children to write their own story. }\end{array}$ & PCK & Orient & Analyze \\
\hline 2.5 .1 & $\begin{array}{l}\text { Learning activity, repeat. Y reiterates the learning activity as it has } \\
\text { been discussed so far allowing for the other teachers to provide more } \\
\text { detail on the learning activity. }\end{array}$ & PCK & Pract & Share \\
\hline 2.5 .2 & $\begin{array}{l}\text { Learning activity, problem. Y introduces a problem: "But what if } \\
\text { Johnny wants to write about a cat and Anny also wants to write about a } \\
\text { cat... what about that?" She furthermore attests that then you would get } \\
\text { two stories. H proposes to make a list and assigning individual children } \\
\text { to only one part of the story. }\end{array}$ & PCK & Pract & Plan \\
\hline 2.5 .3 & $\begin{array}{l}\text { Learning activity, Rationale. Y restates the problem statement and adds } \\
\text { "But a child wants to churn out his own story!" "he will select parts } \\
\text { that he wants to be incorporated into the book!" }\end{array}$ & PCK & Orient & Plan \\
\hline 2.5 .4 & $\begin{array}{l}\text { Learning activity, solution to problem. G reacts by stating that in the } \\
\text { first week only part of the entire story can be written. Other teachers } \\
\text { disagree but also discuss how one story should be divided (into four or } \\
\text { eight consecutive parts and how to designate children). }\end{array}$ & PCK & Pract & Analyze \\
\hline 2.5 .5 & $\begin{array}{l}\text { Learning activity, rationale. G summarizes "I think it is more early } \\
\text { literacy appropriate when children can make their own representation } \\
\text { of the story rather than have them make an exact recreation of the } \\
\text { story!" }\end{array}$ & PCK & Orient & Analyze \\
\hline 2.5 .6 & $\begin{array}{l}\text { Learning activity, think ahead. Y attempts to clarify how she thinks the } \\
\text { on-computer learning activity will be performed, allowing teachers to } \\
\text { respond to her for further clarification. }\end{array}$ & TPCK & Pract & Analyze \\
\hline 2.5 .7 & $\begin{array}{l}\text { Subject-matter. Y takes a sidetrack by asking F "what about nouns?" F } \\
\text { states that nouns should always be represented with their (in Dutch) } \\
\text { respective declaration 'the bus' instead of 'bus'. }\end{array}$ & CK & Extern & Share \\
\hline 2.5 .8 & $\begin{array}{l}\text { Learning activity, link rationale to practice. Y still doubts whether or } \\
\text { not the learning activity will allow children to write their own story. } \\
\text { Then she repeats her earlier proposition: "But still, I think that a child } \\
\text { wants to..." This sentence is finished by H: “... write their own story!" } \\
\text { Y then responds: "But then I think that those pictograms and words } \\
\text { anchor a child's own story. Like those are the anchors which they use } \\
\text { to write or draw." F responds that all of this is feasible possibility in }\end{array}$ & TPCK & Orient & Analyze \\
\hline
\end{tabular}




\begin{tabular}{|c|c|c|c|c|}
\hline & PictoPal & & & \\
\hline 2.5 .9 & $\begin{array}{l}\text { Subject-matter. Y asks F about whether or not children's invented } \\
\text { spelling is allowed. F acknowledges. }\end{array}$ & CK & Extern & Analyze \\
\hline 2.6 .1 & $\begin{array}{l}\text { Learning activity. Teachers expound on grouping and decide that } \\
\text { small-groups ( } 2 \text { or } 3 \text { children) work on one learning activity. }\end{array}$ & TPCK & Pract & Share \\
\hline 2.6 .2 & $\begin{array}{l}\text { Learning activity. Teachers come up with various activities that } \\
\text { children can do with their own written version of the fairytale. }\end{array}$ & PCK & Pract & Share \\
\hline 2.7 .1 & $\begin{array}{l}\text { A points out that in her opinion the learning activity could be too } \\
\text { difficult for children. The other teachers do not pick up this issue. }\end{array}$ & TPCK & Pract & Share \\
\hline 2.7 .2 & $\begin{array}{l}\text { As a response to A, Y proposes to only have the oldest kindergartners } \\
\text { conduct the learning activity. However, H believes that younger } \\
\text { children are also able "to do something with the pictograms.!" }\end{array}$ & PCK & Orient & Analyze \\
\hline 2.7 .3 & $\begin{array}{l}\text { A and } \mathrm{H} \text { discuss how they should keep in mind that the duration of } 8 \\
\text { weeks is maintained. }\end{array}$ & PCK & Pract & Share \\
\hline 2.8 & $\begin{array}{l}\text { Further content is shared, yet teachers state that in the third workshop } \\
\text { they will bring with them a fairy-tale storybook and a list of words that } \\
\text { they would like to be incorporated into PictoPal. }\end{array}$ & TPCK & Pract & Share \\
\hline
\end{tabular}

Table C. Workshop 3 data coding

\begin{tabular}{|c|c|c|c|c|}
\hline TE & Topic & TPCK & Reason & Depth \\
\hline 3.1 .1 & $\begin{array}{l}\text { Evaluate. } \mathrm{R} \text { is introduced as a new member of the design team. She } \\
\text { commenced teaching duty the day before the workshop after a short } \\
\text { period of leave. } \mathrm{H} \text { and } \mathrm{Y} \text { tell } \mathrm{R} \text { the PictoPal learning activity (creating } \\
\text { your own fairy-tale story using words as anchors from an existing } \\
\text { fairy-tale). Also time-planning is discussed. }\end{array}$ & TPCK & Pract & Share \\
\hline 3.1 .2 & $\begin{array}{l}\text { Evaluate. The printer and computer are emerging as problematic. Both } \\
\text { types of hardware are about to be replaced, yet teachers don't know } \\
\text { when this is going to happen. }\end{array}$ & TK & Pract & None \\
\hline 3.1 .3 & $\begin{array}{l}\text { Evaluate, classroom experience. R shares her experience with working } \\
\text { with the prototype activity and the problems related to using these. }\end{array}$ & TPCK & Pract & Share \\
\hline 3.1 .4 & $\begin{array}{l}\text { Explain, prepare todays' workshop. } \mathrm{H} \text { explains how she has divided the } \\
\text { story into segments. }\end{array}$ & TPCK & Pract & Share \\
\hline 3.2 .1 & $\begin{array}{l}\text { Evaluate, classroom experience / practical problem. R furthermore } \\
\text { shares her concerns and illustrates this with the story about how a } \\
\text { particular child with learning difficulties struggled using PictoPal. H } \\
\text { responds that one of the reasons may be that he is not used to playing } \\
\text { with computers. }\end{array}$ & TPK & Pract & Share \\
\hline 3.2 .2 & $\begin{array}{l}\text { Explain practical solution. } \mathrm{H} \text { furthermore explains } \mathrm{R} \text { how she prepared } \\
\text { children to operate the computer and use PictoPal. R however states } \\
\text { that they have a very "difficult class". R is still not satisfied and } \\
\text { explains that children in her class are struggling with using a mouse } \\
\text { (navigating and clicking). She sees this as "very difficult to conceive." }\end{array}$ & TPK & Orient & Analyze \\
\hline 3.2 .3 & $\begin{array}{l}\text { Y asks where the small-sized computer-mice are, stating that she liked } \\
\text { using them. }\end{array}$ & TPK & Pract & Share \\
\hline 3.2 .4 & $\begin{array}{l}\mathrm{R} \text { laments on the printers still being located too far away. F responds } \\
\text { that this issue cannot be resolved as the replacement of computer } \\
\text { hardware is still pending. }\end{array}$ & TK & Pract & Share \\
\hline 3.3.1 & $\begin{array}{l}\text { R illustrates with a classroom example of two children writing their } \\
\text { own story on a computer. She furthermore states that these two } \\
\text { children had advanced skills and therefore were very well able to use } \\
\text { the computer for such a learning activity. Y responds to R that these } \\
\text { children can help children who are less computer skilled. Also H states } \\
\text { that the font used in PictoPal aids these children in writing their own } \\
\text { stories. }\end{array}$ & TPCK & Orient & Analyze \\
\hline 3.3 .2 & $\begin{array}{l}\text { Teachers point their attention to the screen in which PictoPal has been } \\
\text { started. Teachers tell } \mathrm{F} \text { what words they would like and as an example }\end{array}$ & TPCK & Pract & Share \\
\hline
\end{tabular}




\begin{tabular}{|c|c|c|c|c|}
\hline & F shows what the screen will look like. $\mathrm{k}$ & & & \\
\hline 3.3 .3 & $\begin{array}{l}\mathrm{R} \text { expresses her positive attitude towards PictoPal by stating that } \\
\text { children do write their own story and that every day this story is } \\
\text { repeated. She also mentions that such practice is appropriate according } \\
\text { to developmental education kindergartens. }\end{array}$ & TPCK & Extern & Analyze \\
\hline 3.4 .1 & $\begin{array}{l}\mathrm{R} \text { however questions whether children with dyslexia (or other reading } \\
\text { disabilities) will be able to use PictoPal. Especially because the words } \\
\text { used are difficult to read. F responds by stating that is more important } \\
\text { to include words that children are interested, teachers then should read } \\
\text { those words aloud to children. Also F explains that PictoPal is not } \\
\text { meant to foster phonological awareness. }\end{array}$ & PCK & Orient & Analyze \\
\hline 3.4 .2 & $\begin{array}{l}\mathrm{R} \text { urges to use easily readable words. However } \mathrm{H} \text { objects, stating that } \\
\text { making mistakes using PictoPal does little harm. R again objects by } \\
\text { stating that words that have been processes wrong are difficult to } \\
\text { correct. F intervenes by stating that the goal of PictoPal is not enhance } \\
\text { the reading abilities of children. }\end{array}$ & PCK & Orient & Analyze \\
\hline 3.4 .3 & $\begin{array}{l}\text { In this TE F tries to acknowledge R's concerns about children with } \\
\text { reading disability and PictoPal. However, R also urges that "I am not } \\
\text { against what you are saying." Also H expounds on the learning goal of } \\
\text { PictoPal and stresses that learning to functionally decode words is not } \\
\text { one of them. }\end{array}$ & CK & Exter & Analyze \\
\hline 3.4 .4 & $\begin{array}{l}\text { H explains how she prepared for today's workshop by showing how } \\
\text { the story was divided. }\end{array}$ & PCK & Pract & Share \\
\hline 3.5 .1 & H shares various learning activities with PictoPal. & TPCK & Pract & Share \\
\hline 3.5 .2 & Brainstorm about how the screen will look like. & TCK & Pract & Share \\
\hline 3.5 .3 & $\begin{array}{l}\text { Off computer learning activity: children print their book page or cut the } \\
\text { page out and paste it on a large sheet of paper. }\end{array}$ & PCK & Pract & Share \\
\hline 3.5 .4 & $\begin{array}{l}\mathrm{H} \text { explains to } \mathrm{R} \text { that the goal is to make a book with contributions from } \\
\text { all children. }\end{array}$ & TPCK & Pract & Share \\
\hline 3.6 .1 & $\begin{array}{l}\text { R urges that only children who are ready to use computers should do } \\
\text { so. The other teachers agree and acknowledge R's proposal. }\end{array}$ & TPCK & Orient & Plan \\
\hline 3.6 .2 & $\begin{array}{l}\text { Link between PP and functional literacy is discussed. Teachers identify } \\
\text { how PP activity targets this goal. }\end{array}$ & TPCK & External & Plan \\
\hline 3.7 .1 & $\begin{array}{l}\mathrm{R} \text { turns attention once more to the design task and invites teachers to } \\
\text { expedite the design of the learning activity in more detail. }\end{array}$ & TPCK & Pract & Share \\
\hline 3.7 .2 & $\begin{array}{l}\text { Brainstorm about the screen, the kind of pictograms and how they } \\
\text { should be placed on the screen. Furthermore, H proposes that some of } \\
\text { the Pictures she wants to use can be scanned from the fairytale book } \\
\text { she uses in her classroom and can be sent to R. Lengthy ( } 182 \\
\text { interactions) }\end{array}$ & TCK & Pract & Share \\
\hline 3.8 .1 & H proposes that computers from other classrooms can also be used. & TK & Pract & Share \\
\hline 3.8 .2 & $\begin{array}{l}\text { Y provides an event which triggers her belief on the appropriateness of } \\
\text { children using their invented spelling. She furthermore discusses this } \\
\text { belief as it opposes R's belief that "you should teach children the } \\
\text { correct spelling right away". }\end{array}$ & PCK & Orient & Analyze \\
\hline 3.8 .3 & $\begin{array}{l}\mathrm{R} \text { openly asks } \mathrm{F} \text { when invented spelling is not appropriate anymore. } \mathrm{F} \\
\text { responds that he is not an early literacy expert. }\end{array}$ & PCK & External & Analyze \\
\hline 3.8 .4 & $\begin{array}{l}\text { R furthermore brings about the 'rules' that one of the Dutch early } \\
\text { literacy experts tells teachers "let them scribble". Y then explains that } \\
\text { she finds it more important that children are motivated and may "churn } \\
\text { out" instead of. }\end{array}$ & PCK & External & Analyze \\
\hline 3.8 .5 & $\begin{array}{l}\mathrm{R} \text { concludes that motivation is more important than correct spelling } \\
\text { kindergarten. }\end{array}$ & PCK & Orient & Analyze \\
\hline 3.8 .6 & $\begin{array}{l}\text { Teachers discuss the appropriateness of small-cap letters in } \\
\text { kindergarten to avoid confusion. After this, teachers close the meeting } \\
\text { and make an appointment for the installation of PictoPal. }\end{array}$ & CK & External & Analyze \\
\hline
\end{tabular}


Exploring teachers' use of TPACK in design talk 